\title{
Fuzzy Vikor Application for Learning Management Systems Evaluation in Higher Education
}

Sarra Ayouni, Information Systems Department, College of Computer and Information Science, Princess Nourah bint Abdulrahman University, Saudi Arabia

(iD) https://orcid.org/0000-0002-4019-380X

Leila Jamel Menzli, Information Systems Department, College of Computer and Information Science, Princess Nourah bint Abdulrahman University, Saudi Arabia \& Laboratory RIADI, ENSI, Tunisia

Fahima Hajjej, Information Systems Department, College of Computer and Information Science, Princess Nourah bint Abdulrahman University, Saudi Arabia \& LATICE Laboratory, Tunisia

Mohamed Maddeh, Information Systems Department, King Saud University, Riyadh, Saudi Arabia

Shaha Al-Otaibi, Information Systems Department, College of Computer and Information Science, Princess Nourah bint Abdulrahman University, Saudi Arabia

\begin{abstract}
Adopting learning management systems (LMS) in higher education has become a major focus of interest to implement e-learning. Evaluating the quality of LMS is important to improve learner outcomes and promote teaching strategy. Many LMSs are emerging and thus assisting higher institutions to choose the adequate LMS becomes crucial especially under fuzzy environment where uncertainties and subjectivities are considered. Because of this, the paper proposes a quality framework inspired from ISOLIEC 9126 to evaluate and rank proprietary, open source and cloud-based LMSs. Then a Fuzzy Vikor (VlseKriterijumska Optimizacija I Kompromisno Resenje) technique is applied for instantiating the proposed framework criteria and selecting alternatives from three LMSs adopted in Saudi Arabia universities. The obtained results show that the most important criteria for decision makers in these institutions are equally understandability and time behavior. In addition, the open source Moodle was set as the appropriate LMS to meet higher institutions standards.
\end{abstract}

\section{KEYWORDS}

Fuzzy Vikor, Higher Education, Learning Management Systems, Multi-Criteria Decision Making, Quality Framework

\section{INTRODUCTION}

With the progress of information and communication technology development, e-Learning is emerging as the paradigm of modern education (Ülker \& Yilmaz, 2016). In fact, through the past decades e-learning systems have extensively been used in higher educational institutions. They bring

\section{DOI: 10.4018/IJICTE.2021040102}

This article, published as an Open Access article on December 4, 2020 in the gold Open Access journal, International Journal of Information and Communication Technology Education (converted to gold Open Access January 1, 2021), is distributed under the terms of the Creative Commons Attribution License (http://creativecommons.org/licenses/by/4.0/) which permits unrestricted use, distribution, and production in any medium, provided the author of the original work and original publication source are properly credited. 
many advantages for all world academic organizations including liberating interactions between all stakeholders (i.e.; learners and educators or learners and learners) from geographical barriers through the asynchronous and synchronous learning network model (Meirani \& Adrian, 2018), flexibility in accessing learning materials, reduction of costs of classrooms and equipment, etc.

Adopting Learning Management Systems (LMS) in higher education has become a major focus of interest to implement e-Learning. A study was conducted by Aljuhney and Murray (Aljuhney \& Muray, 2016) to investigate the utilization of LMS in 46 higher educational institutions in KSA. The authors concluded that the majority of these institutions (87\%) have been using a LMS. Nevertheless, the adoption and the deployment of a LMS are not sufficient to meet educational goals (e.g.; improve learner outcomes and promote teaching strategy). Evaluating such systems is necessary to measure stakeholder's acceptance and satisfaction and can enable the attainment of these goals (Ghazal, Aldowah, Umar, \& Bervell, 2018). Especially, in the Kingdom of Saudi Arabia (KSA), the e-Learning is increasingly prevalent in higher educational institutions and it is expected to gain even more importance in the future. According to the Saudi Communications and Information Technology Commission (CITC), the KSA is one of the fastest growing countries in the world in terms of e-Learning (LMS, 2019).

A LMS is different from others as it presents its own functions, features (cost, technical support, development, security, etc.) and a huge number of LMS solutions are emerging. Some universities prefer open source LMSs than commercial LMSs. LMSs selection is then becoming important and difficult to higher institutions in order to satisfy their learning and educational requirements. Starting from these facts, we address the problem of LMS evaluation and selection in higher institutions. The purpose of this paper is to define a set of crucial evaluation criteria; by proposing an ISOLIEC 9126-based framework; to be used by decision makers during the selection process. Even more, a fuzzy Vikor method is applied as a multi-criteria decision making technique and a prototype is then developed to support this process

The remain of this paper is organized as follows. Section 2 presents the review of the works related to the domain of the study. The review includes a background information on LMS and MCDM for the evaluation and comparison of LMSs with a focus on higher education field. Section 3 describes the proposed framework for LMSs evaluation inspired from the standard model ISOLIEC 9126 for software quality assurance. Section 4 presents how a fuzzy Vikor technique (Opricovic, 1998); is applied in order to guide LMSs stakeholders in evaluating; by instantiating the proposed framework; three examples of LMSs alternatives in higher Saudi institutions. Finally, section 5 concludes this paper and highlights the future of this work.

\section{RELATED WORK}

In higher institutions, LMSs can be implemented according to three different formats based on delivery modes and proportion of content delivered online including: complete online course, blended course, and web-facilitated courses (Lameras, Levy, Paraskakis, \& Webber, 2012), (Yanbing \& Aihua, 2013). Whatever the adopted format, a LMS is an integral component used for more efficient, active and flexible learning experience. LMSs bring many advantages: facilitate access, interactivity, communication and distribution of information between instructors and learners. It can also facilitate collaboration, cooperation and interaction between learners, making them less time and place dependent (Chourishi, Buttan, Chaurasia, \& Soni, 2011), (Yanbing \& Aihua, 2013).

\section{Learning Management Systems (LMS)}

E-learning can be implemented and empowered by deploying a learning/teaching support system such LMSs which provide adequate tools for organizing, delivering and managing online courses. Hall defines an LMS as Software that provides the platform for the enterprise's online learning environment by enabling the management, delivery and tracking of blended learning (i.e.; online 
and traditional classroom) for employees, stakeholders and customers (Hall, 2019), (Safari, Faraji, \& Majidian, 2014). In an educational context, a LMS is defined in (Ghosh, Nafalski, Nedic, \& Wibawa, 2019) as an online platform developed to facilitate collaborative teaching and learning. This online platform has been emerged in higher educational institutions since the 1990s when traditional classroom experiences were being available online via the internet and redesigned for computer-mediated delivery (Li \& Lee, 2016).

$\mathrm{Li}$ and Lee have stated in ( $\mathrm{Li} \&$ Lee, 2016) that a LMS facilitates the accessibility and exposure to education in the area of advanced technologies. The LMS incorporates several tools for managing and facilitating the activities of learning and teaching (Sun, Tsai, Finger, Chen, $\&$ Yeh, 2008). It provides a collection of tools and functions to support teaching and learning processes, including educational content and resources management tools, tracking of student activities (e.g.; communication and collaboration tools, assignment submissions and student assessment tools) (Althobaiti \& Mayhew, 2015).

A LMS helps educational institusuitabletions maintaining the integrity of their educational programs and enables faculty to effectively and efficiently develop courses, deliver instruction, facilitate communication, foster collaboration, and assess students (Xhaferi, Bahiti, \& Imeri, 2015).

\section{MCDM for LMSs Evaluation and Comparison}

Thanks to the quick technology innovations, many LMSs are present in the market such as proprietary, open source and cloud-based. Each LMS has its own features, advantages and disadvantages. LMSs are evolving and maturing since they emerged on the market in 1990s (Dube \& Scott, 2014), (Moonsamy \& Govender, 2018), (Shemshadi, Shirazi, Toreihi, \& Tarokh, 2011), different examples including Blackboard Learn, Canvas Moodle, Edmodo, Litmos by SAP, Sakai, D2L Brightspace, Acadox, etc.

As mentioned above, higher educational institutions have increased their investments in LMSs; however the evaluation of such systems is still crucial for them (Albarrak A. I., 2010). Indeed, the evaluation of LMS is important to measure the satisfaction of stakeholders and to enable decision makers to identify errors and bad actions, to make predictions, and consequently to optimize investment (Abdel-Maksoud, 2018).

In the literature, many researches are interested to compare and classify various LMSs. In G2 Crowd (Best Coporate LMS Software for 2019, 2019) a LMS evaluation grid is presented which is based on customer satisfaction and market presence (product, scale focus and influence). Similarly, Hill suggests a comparison of LMSs from 2016-2017 based on the market share for US and Canadian (Hill, 2017). In (Cavus \& Zabadi, 2014), the authors conduct a comparison study based on best communication tools of LMSs but only open source software are considered by this work.

Other research teams focus on comparing LMS software for by higher education institutions. In (Xhaferi, Bahiti, \& Imeri, 2015) a comparison of open source and commercial LMSs is conducted in the decision of LMS investment for e-learning purposes. Six criteria are used for this comparison (fee, technical support, hardware and scalability, development, security, integration) and the retained results show that open source LMSs are suitable for technology companies with limit budget. Besides, commercial LMSs are suitable for organizations that do not have software and without budget limitation.

The selection of the adequate LMS by a higher educational institution is a decision based criteria problem as LMS stakeholders are using different criteria to reflect their preferences regarding the LMS features, cost and functions (Fardinpour, 2014). Many researchers have adopted MCDM methods to evaluate LMSs such DEMATEL (Muhammad \& Cavus, 2017), AHP (Alice P.S., 2012), (Işık, Ince, \& Yagit, 2015), ELCETRE (Mastalerz, 2010), TOPSIS (Büyüközkan, Arsenyan, \& Ertek, 2010), (Kang, Kuo, Jia-Hong, \& Sheng-Min, 2011), Fuzzy AHP (Iş1k, Ince, \& Yagit, 2015) and Fuzzy TOPSIS (Turker \& Turker, 2019), etc. Although these works have been fructuous, Fuzzy MCDM techniques are still broad for e-learning compared to its use in other domains (Zarea, et al., 2016) . 


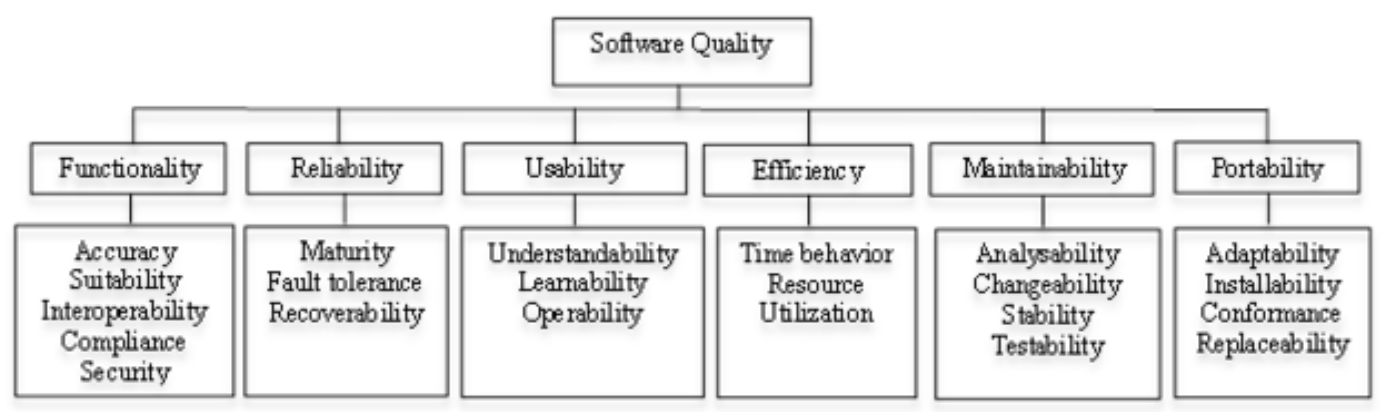

\section{ISOLIEC 9126 BASED QUALITY FRAMEWORK PROPOSAL FOR LMS EVALUATION}

The standard ISO/IEC 9126 is a quality model, which is applied to any software (Padayachee, Kotze, Van, \& Van der Merwe, 2010).

It specifies 22 sub-criteria related to two distinct models for software quality: (i) internal and external quality and (ii) quality in use characteristics as shown in Figure 1.

In (Cavus \& Zabadi, 2014), a theoretical framework is suggested comprising domain specific quality criteria related to the ISOLIEC 9126 and used for some specific software systems. This latter framework is adopted for selecting generic external systems quality characteristics and subcharacteristics that are appropriate for user evaluation of course management system (Persico, Manca, \& Pozzi, 2014). In fact, four quality characteristics are proposed to evaluate the 'quality in use' of e-learning systems from educators' perspectives. These criteria are subjective, as we need to measure the user's perceptions for the quality in use of the most popular LMSs. Each characteristic is subdivided into a set of sub-characteristics.

In this study, 12 retained sub-criteria divided into four criteria inspired from ISOLIEC 9126 model are considered as shown in Table 1.

For every sub-criteria, is assigned a question which helps LMS' stakeholders to evaluate a LMS according to the expert' point of view, as represented in Table 2.

Table 1. ISO9126- based Framework for LMS evaluation

\begin{tabular}{|l|l|}
\hline \multicolumn{1}{|c|}{ Criteria } & \\
\hline Functionality & Sub-Criteria \\
& Accurateness (C2) \\
& Interoperability (C3) \\
& Compliance (C4) \\
& Security (C5) \\
\hline Reliability & Maturity (C6) \\
& Fault tolerance (C7) \\
& Recoverability (C8) \\
\hline Usability & Understandability (C9) \\
& Learnability (C10) \\
& Attractiveness (C11) \\
\hline Efficiency & Time Behavior (C12) \\
\hline
\end{tabular}


Table 2. Questions guidelines for LMSs evaluation

\begin{tabular}{|c|c|c|}
\hline Criteria & Sub-Criteria & Question to be Answered by LMS' Stakeholder (DMs) \\
\hline \multirow[t]{5}{*}{ Functionality } & Suitability (C1) & 'To what extent does the LMS software perform the tasks required?' \\
\hline & Accurateness (C2) & 'To what extent is the result as expected?' \\
\hline & Interoperability (C3) & $\begin{array}{l}\text { 'How much do you estimate the interaction of the system with another } \\
\text { system?' }\end{array}$ \\
\hline & Compliance (C4) & 'To what extent is the system compliant with standards?' \\
\hline & Security (C5) & 'To what extent does the system prevent unauthorized access?' \\
\hline \multirow[t]{3}{*}{ Reliability } & Maturity (C6) & $\begin{array}{l}\text { 'To what extent have most of the defects in the system been removed over } \\
\text { time?' }\end{array}$ \\
\hline & Fault tolerance $(\mathrm{C} 7)$ & 'To what extent is the system capable of handling errors?' \\
\hline & Recoverability (C8) & $\begin{array}{l}\text { 'To what extent can the system resume working \& restore lost data after } \\
\text { failure?' }\end{array}$ \\
\hline \multirow[t]{3}{*}{ Usability } & Understandability(C9) & $\begin{array}{l}\text { 'How much do you estimate the user comprehend how to use the system } \\
\text { easily?' }\end{array}$ \\
\hline & Learnability (C10) & 'To what extent can the user learn to use the system easily?' \\
\hline & Attractiveness (C11) & 'To what extent does the interface look good?' \\
\hline Efficiency & Time Behavior (C12) & 'How quickly does the system respond?' \\
\hline
\end{tabular}

\section{FUZZY VIKOR METHOD FOR LMS EVALUATION: APPLICATION AND RESULTS}

\section{Fuzzy Vikor Method}

Vikor (VlseKriterijumska Optimizacija I Kompromisno Resenje) is a MCDM method introduced by Opricovic in 1998 (Opricovic, 1998) to rank a set of alternatives according to a set of conflicting criteria in order to compromise an ideal solution for a given problem.

The Vikor method is widely applied in decision making problems in various domains (Bazzazi, Osanloo, \& Krimi, 2011), (Jahan, Mustapha, Ismail, Sapuan, \& Bahraminasab, 2011). After introducing the Fuzzy concept in decision-making problems (Bellman \& Zadeh, 1970), the Vikor method was then extended to Fuzzy Vikor to address uncertainty in human judgment preferences (Yücenur \& Demirel, 2012). The Fuzzy Vikor method was used and applied efficiently to solve a wide range of MCDM problems (e.g.; supplier selection problem (Sun, Tsai, Finger, Chen, \& Yeh, 2008), insurance company problem (Zarea, et al., 2016), climate change and variability (Kim \& Chung, 2013), risk management enterprise architecture (Sanchez-Garcia, Amat, Molina, \& Saiz-Colomina, 2018), etc.). In this paper, Fuzzy Vikor method is applied to select one of several LMSs used in higher educational institutions. The different steps of Fuzzy Vikor method are depicted in Figure 2.

\section{Fuzzy Vikor Application: Case Study}

In this section, we are going to propose a numerical example to illustrate an application of the Fuzzy Vikor method. This method is used to evaluate and rank three different LMSs that are used in higher educational institutions. In fact, LMSs evaluation and selection problem can be considered as a MCDM problem where the set of criteria are instantiated from the proposed quality framework given in Table 2. Three categories of decisions makers are involved in this study: expert of LMS (D1), educator (D2) and learner (D3):

- The first category (D1) represents a set of 20 engineers working in E-learning departments in Princess Nourah bint Abdulrahman University colleges and associated deanships; 
Figure 2. Fuzzy Vikor steps

\section{Define the set of criteria and sub criteria}

\section{Create list alternatives}

Identify decision makers

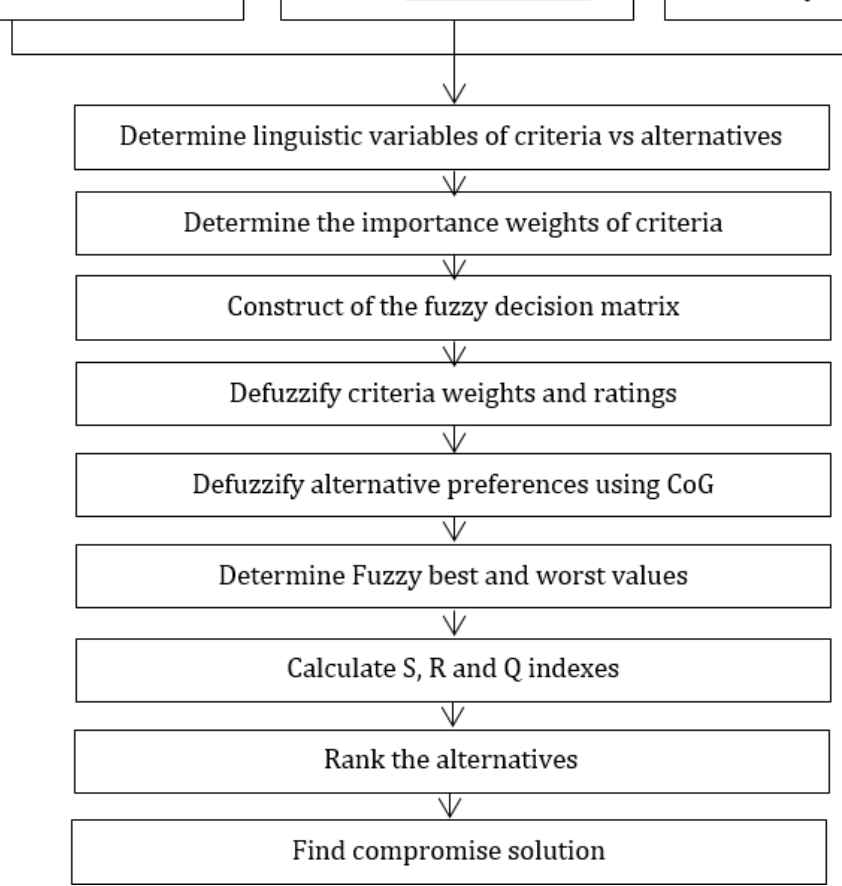

- The second category (D2) represents a set of 250 faculty members from the four PNU' scientific colleges (College of Computer and Information Sciences, College of Business Administration, College of Sciences and College of Engineering);

- The third category (D3) represents a set of 890 students of PNU who are familiar with different LMSs. The set is a simple random set of undergraduate students scattered over the four college of sciences at different levels of study.

A simple random technique is used in this study where everyone (for the three DMs categories) in the population of interest has an equal chance to being selected as a research participant.

In what follows, we trace the different steps of the Fuzzy Vikor method.

Step1: Determination of the linguistic variables.

Linguistic variables are qualitative words or phrases of a natural language that reflects the subjective point of view of an expert about a predefined set of criteria.

Table 3 shows the linguistics terms used for evaluating respectively the criteria $(\mathrm{C} 1, \mathrm{C} 2$..., $\mathrm{C} 12)$ and the LMSs (Alternatives): Blackboard (A1), Moodle (A2) and D2L (A3) by decision makers (DMs). For each term, we associate a triangular fuzzy number.

Step 2: Determination of the importance weights of criteria. 
Table 3. Linguistic scale for criteria and alternatives importance

\begin{tabular}{|l|l|l|}
\hline \multirow{4}{*}{ Criteria } & \multicolumn{1}{|c|}{ Linguistic Terms } & \multicolumn{1}{c|}{ Triangular Fuzzy Number } \\
\cline { 2 - 3 } & Very Low (VL) & $(0.0,0.1,0.3)$ \\
\cline { 2 - 3 } & Low $(\mathbf{L})$ & $(0.1,0.3,0.5)$ \\
\cline { 2 - 3 } & Medium (M) & $(0.3,0.5,0.7)$ \\
\cline { 2 - 3 } Alternatives & High (H) & $(0.5,0.7,0.9)$ \\
\cline { 2 - 3 } & Very High (VH) & $(0.7,0.9,1.0)$ \\
\hline & Poor $(\mathbf{P})$ & $(0.0,0.2,0.4)$ \\
\cline { 2 - 3 } & Fair $(\mathbf{F})$ & $(0.2,0.4,0.6)$ \\
\cline { 2 - 3 } & Good $(\mathbf{G})$ & $(0.4,0.6,0.8)$ \\
\cline { 2 - 3 } & Very Good $(\mathbf{V G})$ & $(0.6,0.8,1.0)$ \\
\hline
\end{tabular}

Three decisions makers are involved in this study: expert of LMS (D1), educator (D2) and learner (D3) which assign importance to the criteria by using the linguistic terms of Table 2. Then each obtained value is transformed into triangular fuzzy number as shown in Table 4.

The decision makers 'opinions are then aggregated by using the graded mean integration method [17]. For each criteria $\mathrm{Cj}$ is associated a fuzzy importance $\widetilde{w_{j}}$ computed by Equation 1 :

$\tilde{w}_{j}^{k}=\left(w_{j 1}, w_{j 2}, w_{j 3}\right)$

where $\mathrm{k}$ is the number of DMs and:

$w_{j 1}=\min _{k}\left\{w_{j k 1}\right\} ;$ for $\mathbf{j}=1 \ldots . . \mathrm{n}$ (n number of criteria)

$w_{j 2}=\frac{1}{k} \sum_{k=1}^{k} w_{j k 2} ;$ for $\mathbf{j}=1 \ldots . . \mathrm{n}$ (n number of criteria)

$w_{j 3}=\max \left\{w_{j k 3}\right\} ;$ for $\mathbf{j}=1 \ldots . . \mathrm{n}$ (n number of criteria)

In order to determine the importance of each criteria, every $\widetilde{w_{j}}$ is defuzzified by using the COA (Center Of Area) method. For each Cj a BNF (Best Non-Fuzzy Performance) value is calculated using the Equation 2. Values obtained are shown in Table 5:

$B N P_{j}=L_{j}+\left[\left(U_{j}-L_{j}\right)+\left(M_{j}-L_{j}\right)\right] / 3$

where $\widetilde{w_{j}}=\left(L_{j}, M_{j}, U_{j}\right)$.

Step 3: Construction of the fuzzy decision matrix (alternatives vs criteria). 
Table 4. Importance weights of criteria and corresponding triangular fuzzy numbers

\begin{tabular}{|c|c|c|c|}
\hline & $\mathrm{D}_{1}$ & $\mathbf{D}_{2}$ & $\mathbf{D}_{3}$ \\
\hline \multirow[t]{2}{*}{$\mathrm{C}_{1}$} & $\mathrm{~L}$ & VH & $\mathrm{L}$ \\
\hline & $(0.1,0.3,0.5)$ & $(0.7,0.9,1.0)$ & $(0.1,0.3,0.5)$ \\
\hline \multirow[t]{2}{*}{$\mathrm{C}_{2}$} & M & $\mathrm{VH}$ & $\mathrm{H}$ \\
\hline & $(0.3,0.5,0.7$ & $(0.7,0.9,1.0)$ & $(0.5,0.7,0.9)$ \\
\hline \multirow[t]{2}{*}{$\mathrm{C}_{3}$} & $\mathrm{VL}$ & $\mathrm{H}$ & $\mathrm{L}$ \\
\hline & $(0.0,0.1,0.3)$ & $(0.5,0.7,0.9)$ & $(0.1,0.3,0.5)$ \\
\hline \multirow[t]{2}{*}{$\mathrm{C}_{4}$} & VL & $\mathrm{L}$ & $\mathrm{H}$ \\
\hline & $(0.0,0.1,0.3)$ & $(0.1,0.3,0.5)$ & $(0.5,0.7,0.9)$ \\
\hline \multirow[t]{2}{*}{$\mathrm{C}_{5}$} & M & $\mathrm{H}$ & $\mathrm{VH}$ \\
\hline & $(0.3,0.5,0.7$ & $(0.5,0.7,0.9)$ & $(0.7,0.9,1.0)$ \\
\hline \multirow[t]{2}{*}{$\mathrm{C}_{6}$} & VL & $\mathrm{L}$ & $\mathrm{VH}$ \\
\hline & $(0.0,0.1,0.3)$ & $(0.1,0.3,0.5)$ & $(0.7,0.9,1.0$ \\
\hline \multirow[t]{2}{*}{$\mathrm{C}_{7}$} & VL & M & $\mathrm{H}$ \\
\hline & $(0.0,0.1,0.3)$ & $(0.3,0.5,0.7$ & $(0.5,0.7,0.9)$ \\
\hline \multirow[t]{2}{*}{$\mathrm{C}_{8}$} & $\mathrm{VH}$ & $\mathrm{VH}$ & $\mathrm{H}$ \\
\hline & $(0.7,0.9,1.0)$ & $(0.7,0.9,1.0)$ & $(0.5,0.7,0.9)$ \\
\hline \multirow[t]{2}{*}{$\mathrm{C}_{9}$} & M & $\mathrm{VH}$ & $\mathrm{VH}$ \\
\hline & $(0.3,0.5,0.7$ & $(0.7,0.9,1.0)$ & $(0.7,0.9,1.0)$ \\
\hline \multirow[t]{2}{*}{$\mathrm{C}_{10}$} & $\mathrm{VH}$ & M & $\mathrm{H}$ \\
\hline & $(0.7,0.9,1.0)$ & $(0.3,0.5,0.7$ & $(0.5,0.7,0.9)$ \\
\hline \multirow[t]{2}{*}{$\mathbf{C}_{11}$} & $\mathrm{VH}$ & $\mathrm{H}$ & M \\
\hline & $(0.7,0.9,1.0)$ & $(0.5,0.7,0.9)$ & $(0.3,0.5,0.7$ \\
\hline \multirow[t]{2}{*}{$\mathrm{C}_{12}$} & $\mathrm{VH}$ & $\mathrm{VH}$ & $\mathrm{VH}$ \\
\hline & $(0.7,0.9,1.0)$ & $(0.7,0.9,1.0)$ & $(0.7,0.9,1.0)$ \\
\hline
\end{tabular}

The evaluation of the three LMSs (i.e.; Blackboard, Moodle and D2L) based on the twelve criteria can vary from a decision maker to another. Table 6 summarizes the preferences; denoted by a triplet $x_{i j}^{k}=\left(a_{i j}^{k}, b_{i j}^{k}, c_{i j}^{k}\right)$ of the three DMs using Table 3 and corresponding fuzzy triangular values.

The obtained opinions of all DMs to the three alternatives are aggregated using Equation 3. and represented in an aggregated matrix (Table 7). The general term of the matrix is denoted by $\tilde{x}_{i j}^{k}$ :

$$
\tilde{x}_{i j}^{k}=\left(a_{i j}^{k}, b_{i j}^{k}, c_{i j}^{k}\right)
$$

where $\mathrm{k}$ is the number of DMs and:

$a_{i j}=\min _{k}\left\{a_{i j}^{k}\right\} ;$ for $\mathrm{i}=1 \ldots . \mathrm{n}$ (n number of alternatives) 
Table 5. Importance weights of criteria and their corresponding triangular fuzzy numbers

\begin{tabular}{|c|c|c|}
\hline & $\tilde{w}_{j}$ & $B N P_{j}$ \\
\hline $\mathrm{C}_{1}$ & $(0.1,0.5,1)$ & 0.53 \\
\hline $\mathrm{C}_{2}$ & $(0.3,0.7,1)$ & 0.66 \\
\hline $\mathrm{C}_{3}$ & $(0,0.36,0.9)$ & 0.42 \\
\hline $\mathrm{C}_{4}$ & $(0,0.36,0.9)$ & 0.42 \\
\hline $\mathrm{C}_{5}$ & $(0.3,0.7,1)$ & 0.66 \\
\hline $\mathrm{C}_{6}$ & $(0,0.43,1)$ & 0.47 \\
\hline $\mathrm{C}_{7}$ & $(0,0.43,0.9)$ & 0.44 \\
\hline $\mathrm{C}_{8}$ & $(0.5,0.83,1)$ & 0.77 \\
\hline $\mathrm{C}_{9}$ & $(0.7,0.9,1)$ & 0.86 \\
\hline $\mathrm{C}_{10}$ & $(0.3,0.7,1)$ & 0.66 \\
\hline $\mathrm{C}_{11}$ & $(0.3,0.7,1)$ & 0.66 \\
\hline $\mathrm{C}_{12}$ & $(0.7,0.9,1)$ & 0.86 \\
\hline
\end{tabular}

$b_{i j}=\frac{1}{k} \sum_{k=1}^{k} b_{i j}^{k} ;$ for $\mathrm{j}=1 \ldots . \mathrm{m}$ (m number of criteria)

$c_{i j}=\max \left\{c_{i j}^{k}\right\}$; for $\mathbf{j}=1 \ldots . . \mathrm{n}$ (n number of criteria) la difference

Step 4: De-fuzzing criteria weights and ratings.

Vikor approach uses the $\mathrm{CoG}$ (Centroid method or Center of Gravity) to de-fuzzy the values given in Table 5 and Table 7. The obtained crisp values are collected in Table 8. Equation 4. and Equation 5. are respectively used to calculate crisps values for criteria 'weights and the alternatives' preferences:

$$
\begin{aligned}
& \operatorname{CoG}\left(\tilde{w}_{j}\right)=\left(w_{j 1}+w_{j 2}+w_{j 3}\right) / 3 \\
& \operatorname{CoG}\left(\tilde{x}_{j}\right)=\left(a_{j 1}+b_{j 2}+c_{j 3}\right) / 3
\end{aligned}
$$

Step 5: Fuzzy best and worst values.

As DMs' objectives are to maximize the benefits from the evaluation criteria, Vikor approach determines two important values: fuzzy best value $f_{j}^{+}$and fuzzy worst value $f_{j}^{-}$using Equation 6 . The results are shown in Table 9: 
Table 6. DMs' preferences for Blackboard, Moodle and D2L

\begin{tabular}{|c|c|c|c|c|}
\hline DM & Criteria & \multicolumn{3}{|c|}{ Alternatives } \\
\hline \multirow{13}{*}{$\mathbf{D}_{1}$} & & $A_{1}$ & $\mathrm{~A}_{2}$ & $\mathrm{~A}_{3}$ \\
\hline & $\mathrm{C}_{1}$ & $\begin{array}{l}\text { VG } \\
(0.6,0.8,1.0)\end{array}$ & $\begin{array}{l}\text { VG } \\
(0.6,0.8,1.0)\end{array}$ & $\begin{array}{l}\mathrm{G} \\
(0.4,0.6,0.8)\end{array}$ \\
\hline & $\mathrm{C}_{2}$ & $\begin{array}{l}\text { VG } \\
(0.6,0.8,1.0)\end{array}$ & $\begin{array}{l}\text { VG } \\
(0.6,0.8,1.0)\end{array}$ & $\begin{array}{l}\mathrm{F} \\
(0.2,0.4,0.6)\end{array}$ \\
\hline & $\mathrm{C}_{3}$ & $\begin{array}{l}\mathrm{G} \\
(0.4,0.6,0.8)\end{array}$ & $\begin{array}{l}\mathrm{G} \\
(0.4,0.6,0.8)\end{array}$ & $\begin{array}{l}\mathrm{P} \\
(0.0,0.2,0.4)\end{array}$ \\
\hline & $\mathrm{C}_{4}$ & $\begin{array}{l}\text { VG } \\
(0.6,0.8,1.0)\end{array}$ & $\begin{array}{l}\text { VG } \\
(0.6,0.8,1.0)\end{array}$ & $\begin{array}{l}\mathrm{P} \\
(0.0,0.2,0.4)\end{array}$ \\
\hline & $\mathrm{C}_{5}$ & $\begin{array}{l}\text { VG } \\
(0.6,0.8,1.0)\end{array}$ & $\begin{array}{l}\text { VG } \\
(0.6,0.8,1.0)\end{array}$ & $\begin{array}{l}\mathrm{P} \\
(0.0,0.2,0.4)\end{array}$ \\
\hline & $\mathrm{C}_{6}$ & $\begin{array}{l}\mathrm{G} \\
(0.4,0.6,0.8)\end{array}$ & $\begin{array}{l}\mathrm{G} \\
(0.4,0.6,0.8)\end{array}$ & $\begin{array}{l}\mathrm{G} \\
(0.4,0.6,0.8)\end{array}$ \\
\hline & $\mathrm{C}_{7}$ & $\begin{array}{l}\mathrm{G} \\
(0.4,0.6,0.8)\end{array}$ & $\begin{array}{l}\mathrm{G} \\
(0.4,0.6,0.8)\end{array}$ & $\begin{array}{l}\mathrm{F} \\
(0.2,0.4,0.6)\end{array}$ \\
\hline & $\mathrm{C}_{8}$ & $\begin{array}{l}\text { G } \\
(0.4,0.6,0.8)\end{array}$ & $\begin{array}{l}\mathrm{G} \\
(0.4,0.6,0.8)\end{array}$ & $\begin{array}{l}\mathrm{P} \\
(0.0,0.2,0.4)\end{array}$ \\
\hline & $\mathrm{C}_{9}$ & $\begin{array}{l}\mathrm{F} \\
(0.2,0.4,0.6)\end{array}$ & $\begin{array}{l}\mathrm{G} \\
(0.4,0.6,0.8)\end{array}$ & $\begin{array}{l}\mathrm{G} \\
(0.4,0.6,0.8)\end{array}$ \\
\hline & $\mathrm{C}_{10}$ & $\begin{array}{l}\mathrm{F} \\
(0.2,0.4,0.6)\end{array}$ & $\begin{array}{l}\mathrm{F} \\
(0.2,0.4,0.6)\end{array}$ & $\begin{array}{l}\mathrm{G} \\
(0.4,0.6,0.8)\end{array}$ \\
\hline & $\mathrm{C}_{11}$ & $\begin{array}{l}\mathrm{F} \\
(0.2,0.4,0.6)\end{array}$ & $\begin{array}{l}\mathrm{F} \\
(0.2,0.4,0.6)\end{array}$ & $\begin{array}{l}\mathrm{F} \\
(0.2,0.4,0.6)\end{array}$ \\
\hline & $\mathrm{C}_{12}$ & $\begin{array}{l}\mathrm{G} \\
(0.4,0.6,0.8)\end{array}$ & $\begin{array}{l}\mathrm{G} \\
(0.4,0.6,0.8)\end{array}$ & $\begin{array}{l}\mathrm{F} \\
(0.2,0.4,0.6)\end{array}$ \\
\hline \multirow{12}{*}{$\mathbf{D}_{2}$} & $\mathrm{C}_{1}$ & $\begin{array}{l}\text { VG } \\
(0.6,0.8,1.0)\end{array}$ & $\begin{array}{l}\text { VG } \\
(0.6,0.8,1.0)\end{array}$ & $\begin{array}{l}\mathrm{G} \\
(0.4,0.6,0.8)\end{array}$ \\
\hline & $\mathrm{C}_{2}$ & $\begin{array}{l}\text { VG } \\
(0.6,0.8,1.0)\end{array}$ & $\begin{array}{l}\text { VG } \\
(0.6,0.8,1.0)\end{array}$ & $\begin{array}{l}\mathrm{G} \\
(0.4,0.6,0.8)\end{array}$ \\
\hline & $\mathrm{C}_{3}$ & $\begin{array}{l}\text { VG } \\
(0.6,0.8,1.0)\end{array}$ & $\begin{array}{l}\mathrm{G} \\
(0.4,0.6,0.8)\end{array}$ & $\begin{array}{l}\mathrm{P} \\
(0.0,0.2,0.4)\end{array}$ \\
\hline & $\mathrm{C}_{4}$ & $\begin{array}{l}\text { VG } \\
(0.6,0.8,1.0)\end{array}$ & $\begin{array}{l}\text { VG } \\
(0.6,0.8,1.0)\end{array}$ & $\begin{array}{l}\mathrm{F} \\
(0.2,0.4,0.6)\end{array}$ \\
\hline & $\mathrm{C}_{5}$ & $\begin{array}{l}\text { VG } \\
(0.6,0.8,1.0)\end{array}$ & $\begin{array}{l}\text { VG } \\
(0.6,0.8,1.0)\end{array}$ & $\begin{array}{l}\mathrm{G} \\
(0.4,0.6,0.8)\end{array}$ \\
\hline & $\mathrm{C}_{6}$ & $\begin{array}{l}\mathrm{G} \\
(0.4,0.6,0.8)\end{array}$ & $\begin{array}{l}\mathrm{G} \\
(0.4,0.6,0.8)\end{array}$ & $\begin{array}{l}\mathrm{P} \\
(0.0,0.2,0.4)\end{array}$ \\
\hline & $\mathrm{C}_{7}$ & $\begin{array}{l}\mathrm{G} \\
(0.4,0.6,0.8)\end{array}$ & $\begin{array}{l}\mathrm{G} \\
(0.4,0.6,0.8)\end{array}$ & $\begin{array}{l}\mathrm{F} \\
(0.2,0.4,0.6)\end{array}$ \\
\hline & $\mathrm{C}_{8}$ & $\begin{array}{l}\mathrm{G} \\
(0.4,0.6,0.8)\end{array}$ & $\begin{array}{l}\text { VG } \\
(0.6,0.8,1.0)\end{array}$ & $\begin{array}{l}\mathrm{P} \\
(0.0,0.2,0.4)\end{array}$ \\
\hline & $\mathrm{C}_{9}$ & $\begin{array}{l}\text { G } \\
(0.4,0.6,0.8)\end{array}$ & $\begin{array}{l}\mathrm{G} \\
(0.4,0.6,0.8)\end{array}$ & $\begin{array}{l}\text { VG } \\
(0.6,0.8,1.0)\end{array}$ \\
\hline & $\mathrm{C}_{10}$ & $\begin{array}{l}\text { G } \\
(0.4,0.6,0.8)\end{array}$ & $\begin{array}{l}\text { VG } \\
(0.6,0.8,1.0)\end{array}$ & $\begin{array}{l}\mathrm{P} \\
(0.0,0.2,0.4)\end{array}$ \\
\hline & $\mathrm{C}_{11}$ & $\begin{array}{l}\text { VG } \\
(0.6,0.8,1.0)\end{array}$ & $\begin{array}{l}\text { VG } \\
(0.6,0.8,1.0)\end{array}$ & $\begin{array}{l}\mathrm{F} \\
(0.2,0.4,0.6)\end{array}$ \\
\hline & $\mathrm{C}_{12}$ & $\begin{array}{l}\mathrm{G} \\
(0.4,0.6,0.8)\end{array}$ & $\begin{array}{l}\mathrm{G} \\
(0.4,0.6,0.8)\end{array}$ & $\begin{array}{l}\mathrm{G} \\
(0.4,0.6,0.8)\end{array}$ \\
\hline
\end{tabular}


Table 6. Continued

\begin{tabular}{|c|c|c|c|c|}
\hline DM & Criteria & \multicolumn{3}{|c|}{ Alternatives } \\
\hline \multirow{12}{*}{ D3 } & $\mathrm{C}_{1}$ & $\begin{array}{l}\text { VG } \\
(0.6,0.8,1.0)\end{array}$ & $\begin{array}{l}\text { VG } \\
(0.6,0.8,1.0)\end{array}$ & $\begin{array}{l}\text { G } \\
(0.4,0.6,0.8)\end{array}$ \\
\hline & $\mathrm{C}_{2}$ & $\begin{array}{l}\text { VG } \\
(0.6,0.8,1.0)\end{array}$ & $\begin{array}{l}\text { VG } \\
(0.6,0.8,1.0)\end{array}$ & $\begin{array}{l}\mathrm{F} \\
(0.2,0.4,0.6)\end{array}$ \\
\hline & $\mathrm{C}_{3}$ & $\begin{array}{l}\mathrm{F} \\
(0.2,0.4,0.6)\end{array}$ & $\begin{array}{l}\mathrm{G} \\
(0.4,0.6,0.8)\end{array}$ & $\begin{array}{l}\mathrm{P} \\
(0.0,0.2,0.4)\end{array}$ \\
\hline & $\mathrm{C}_{4}$ & $\begin{array}{l}\mathrm{G} \\
(0.4,0.6,0.8)\end{array}$ & $\begin{array}{l}\text { VG } \\
(0.6,0.8,1.0)\end{array}$ & $\begin{array}{l}\mathrm{F} \\
(0.2,0.4,0.6)\end{array}$ \\
\hline & $\mathrm{C}_{5}$ & $\begin{array}{l}\text { VG } \\
(0.6,0.8,1.0)\end{array}$ & $\begin{array}{l}\text { VG } \\
(0.6,0.8,1.0)\end{array}$ & $\begin{array}{l}\text { G } \\
(0.4,0.6,0.8)\end{array}$ \\
\hline & $\mathrm{C}_{6}$ & $\begin{array}{l}\text { G } \\
(0.4,0.6,0.8)\end{array}$ & $\begin{array}{l}\text { G } \\
(0.4,0.6,0.8)\end{array}$ & $\begin{array}{l}\mathrm{P} \\
(0.0,0.2,0.4)\end{array}$ \\
\hline & $\mathrm{C}_{7}$ & $\begin{array}{l}\mathrm{G} \\
(0.4,0.6,0.8)\end{array}$ & $\begin{array}{l}\text { VG } \\
(0.6,0.8,1.0)\end{array}$ & $\begin{array}{l}\mathrm{F} \\
(0.2,0.4,0.6)\end{array}$ \\
\hline & $\mathrm{C}_{8}$ & $\begin{array}{l}\mathrm{G} \\
(0.4,0.6,0.8)\end{array}$ & $\begin{array}{l}\text { G } \\
(0.4,0.6,0.8)\end{array}$ & $\begin{array}{l}\mathrm{G} \\
(0.4,0.6,0.8)\end{array}$ \\
\hline & $\mathrm{C}_{9}$ & $\begin{array}{l}\mathrm{G} \\
(0.4,0.6,0.8)\end{array}$ & $\begin{array}{l}\text { VG } \\
(0.6,0.8,1.0)\end{array}$ & $\begin{array}{l}\text { VG } \\
(0.6,0.8,1.0)\end{array}$ \\
\hline & $\mathrm{C}_{10}$ & $\begin{array}{l}\text { VG } \\
(0.6,0.8,1.0)\end{array}$ & $\begin{array}{l}\mathrm{G} \\
(0.4,0.6,0.8)\end{array}$ & $\begin{array}{l}\text { G } \\
(0.4,0.6,0.8)\end{array}$ \\
\hline & $\mathrm{C}_{11}$ & $\begin{array}{l}\mathrm{G} \\
(0.4,0.6,0.8)\end{array}$ & $\begin{array}{l}\text { VG } \\
(0.6,0.8,1.0)\end{array}$ & $\begin{array}{l}\text { VG } \\
(0.6,0.8,1.0)\end{array}$ \\
\hline & $\mathrm{C}_{12}$ & $\begin{array}{l}\text { G } \\
(0.4,0.6,0.8)\end{array}$ & $\begin{array}{l}\mathrm{G} \\
(0.4,0.6,0.8)\end{array}$ & $\begin{array}{l}\mathrm{G} \\
(0.4,0.6,0.8)\end{array}$ \\
\hline
\end{tabular}

Table 7. Aggregated fuzzy matrix

\begin{tabular}{|l|l|l|l|}
\hline & \multicolumn{1}{|c|}{$\mathbf{A}_{\mathbf{1}}$} & \multicolumn{1}{|c|}{$\mathbf{A}_{2}$} & \multicolumn{1}{|c|}{$\mathbf{A}_{3}$} \\
\hline $\mathrm{C}_{\mathbf{1}}$ & $(0.60,0.80,1.00)$ & $(0.60,0.80,1.00)$ & $(0.40,0.6,0.80)$ \\
\hline $\mathrm{C}_{\mathbf{2}}$ & $(0.60,0.80,1.00)$ & $(0.60,0.80,1.00)$ & $(0.20,0.47,0.80)$ \\
\hline $\mathrm{C}_{\mathbf{3}}$ & $(0.20,0.60,1.00)$ & $(0.40,0.60,0.80)$ & $(0.00,0.20,0.40)$ \\
\hline $\mathrm{C}_{\mathbf{4}}$ & $(0.40,0.73,1.00)$ & $(0.60,0.80,1.00)$ & $(0.00,0.33,0.60)$ \\
\hline $\mathrm{C}_{\mathbf{5}}$ & $(0.60,0.80,1.00)$ & $(0.60,0.80,1.00)$ & $(0.00,0.47,0.80)$ \\
\hline $\mathrm{C}_{\mathbf{6}}$ & $(0.40,0.60,0.80)$ & $(0.40,0.60,0.80)$ & $(0.00,0.33,0.80)$ \\
\hline $\mathrm{C}_{\mathbf{7}}$ & $(0.40,0.60,0.80)$ & $(0.40,0.67,1.00)$ & $(0.20,0.40,0.60)$ \\
\hline $\mathrm{C}_{\mathbf{8}}$ & $(0.40,0.60,0.80)$ & $(0.40,0.67,1.00)$ & $(0.0,0.33,0.80)$ \\
\hline $\mathrm{C}_{\mathbf{9}}$ & $(0.20,0.53,0.80)$ & $(0.40,0.67,1.00)$ & $(0.40,0.73,1.00)$ \\
\hline $\mathrm{C}_{\mathbf{1 0}}$ & $(0.20,0.60,1.00)$ & $(0.20,0.60,1.00)$ & $(0.00,0.47,0.80)$ \\
\hline $\mathrm{C}_{\mathbf{1 1}}$ & $(0.20,0.60,1.00)$ & $(0.20,0.67,1.00)$ & $(0.20,0.53,1.00)$ \\
\hline $\mathrm{C}_{\mathbf{1 2}}$ & $(0.40,0.60,0.80)$ & $(0.40,0.60,0.80)$ & $(0.20,0.53,0.80)$ \\
\hline
\end{tabular}


Table 8. Crisp values for criteria weight and alternatives preferences

\begin{tabular}{|l|c|c|c|c|c|c|c|c|c|c|c|c|}
\hline & $\mathbf{C}_{1}$ & $\mathbf{C}_{2}$ & $\mathbf{C}_{3}$ & $\mathbf{C}_{4}$ & $\mathbf{C}_{5}$ & $\mathbf{C}_{\mathbf{6}}$ & $\mathbf{C}_{7}$ & $\mathbf{C}_{8}$ & $\mathbf{C}_{9}$ & $\mathbf{C}_{10}$ & $\mathbf{C}_{11}$ & $\mathbf{C}_{12}$ \\
\hline $\mathbf{C o G}$ & 0.53 & 0.67 & 0.42 & 0.42 & 0.67 & 0.48 & 0.44 & 0.78 & 0.87 & 0.67 & 0.67 & 0.87 \\
\hline $\mathbf{A}_{1}$ & 0.8 & 0.8 & 0.60 & 0.71 & 0.8 & 0.6 & 0.6 & 0.6 & 0.51 & 0.6 & 0.6 & 0.6 \\
\hline $\mathbf{A}_{2}$ & 0.8 & 0.8 & 0.6 & 0.8 & 0.8 & 0.6 & 0.69 & 0.69 & 0.69 & 0.6 & 0.62 & 0.6 \\
\hline $\mathbf{A}_{3}$ & 0.6 & 0.49 & 0.2 & 0.31 & 0.42 & 0.38 & 0.4 & 0.38 & 0.71 & 0.42 & 0.58 & 0.51 \\
\hline
\end{tabular}

Table 9. Best and worst crisp values for criteria

\begin{tabular}{|c|c|c|c|c|c|c|c|c|c|c|c|c|}
\hline & $\mathrm{C}_{1}$ & $\mathrm{C}_{2}$ & $\mathrm{C}_{3}$ & $\mathrm{C}_{4}$ & $\mathrm{C}_{5}$ & $\mathrm{C}_{6}$ & $\mathrm{C}_{7}$ & $\mathrm{C}_{8}$ & $\mathrm{C}_{9}$ & $\mathrm{C}_{10}$ & $\mathrm{C}_{11}$ & $C_{12}$ \\
\hline$f_{j}^{+}$ & 0.8 & 0.8 & 0.60 & 0.8 & 0.8 & 0.6 & 0.69 & 0.69 & 0.71 & 0.6 & 0.62 & 0.6 \\
\hline$f_{j}^{-}$ & 0.6 & 0.49 & 0.2 & 0.31 & 0.42 & 0.38 & 0.4 & 0.38 & 0.51 & 0.42 & 0.58 & 0.51 \\
\hline
\end{tabular}

$f_{j}^{+}=\max \left\{x_{i j}\right\}$ and $f_{j}^{-}=\min \left\{x_{i j}\right\} ; \mathrm{j}=1 \ldots \mathrm{m}$ (number of criteria)

Step 6: Calculation of $S, R$ and $Q$ indexes.

For each alternative, an index $S_{i}$ is calculated, which refers to the separation measure of the ith alternative with the best value using Equation 7. An index $R_{i}$ is also calculated which refers to the separation measure for the ith alternative to the worst value using Equation 8. Then Equation 9 uses $S_{i}$ and $R_{i}$ values to calculate the $Q_{i}$ index. The results are collected in Table 10:

$S_{i}=\sum_{j=1}^{n} w_{j}\left[\left(f_{j}^{+}-x_{i j}\right) /\left(f_{j}^{+}-f_{j}^{-}\right)\right]$

Table 10. S, $R$ and $Q$ values

\begin{tabular}{|l|l|l|l|}
\hline & \multicolumn{1}{|c|}{$A_{1}$} & \multicolumn{1}{|c|}{$A_{2}$} & \multicolumn{1}{c|}{$A_{3}$} \\
\hline$S$ & 1.64 & 1.76 & 6.61 \\
\hline$R$ & 0.87 & 0.93 & 0.87 \\
\hline$Q$ & 0.59 & 0.00 & 1.00 \\
\hline
\end{tabular}




$$
\begin{aligned}
& R_{i}=\max _{j} w_{j}\left[\left(f_{j}^{+}-x_{i j}\right) /\left(f_{j}^{+}-f_{j}^{-}\right)\right] \\
& Q_{i}=v \frac{S_{i}-S_{\text {min }}}{S_{\text {max }}-S_{\text {min }}}+(1-v) \frac{R_{i}-R_{\text {min }}}{R_{\text {max }}-R_{\text {min }}}
\end{aligned}
$$

where:

- $v$ is the strategy weight for the maximum group utility $(v=(n+1) / 2 n) \cdot n$ is the number of criteria;

- $w_{j}$ is the weight of the jth criteria;

- $S_{\min }=\min _{i} S_{i}, R_{\min }=\min _{i} R_{i}$

- $S_{\max }=\max _{i} S_{i}, R_{\max }=\max _{i} R_{i}$

Step 7: Rank the alternatives.

Using $S_{i}, R_{i}$ and $Q_{i}$ values, the $A_{i}$ are ranked in an ascending order as represented in Table 11. The index $Q_{i}$ reflects the separation of the alternative $A_{i}$ from the best value. The best alternative is the one that has the smaller $Q_{i}$.

Step 8: A compromise solution proposal.

We symbolize $A^{* *}, A^{*}$ respectively the LMS retained in step 7 (with the minimum Q) and the LMS in the second position (Q ranking). $A^{* *}$ can be considered as a promising alternative if the two below conditions are satisfied (Cond.1 and Cond.2):

(Cond.1) $A d v=Q\left(A^{*}\right)-Q\left(A^{* *}\right) \geq(1 / m-1)$

where $\mathrm{m}$ is the number of criterion:

(Cond.2) $S\left(A^{* *}\right) \geq S\left(A^{*}\right)$ and/ or $R\left(A^{* *}\right) \geq R\left(A^{*}\right)$

Table 11. Ranking of alternatives using $S_{i}, R_{i}$ and $Q_{i}$

\begin{tabular}{|l|l|}
\hline & Alternatives' Ranks \\
\hline$S_{i}$ & $A_{2}>A_{1}>A_{3}$ \\
\hline$R_{i}$ & $A_{2}>A_{1}=A_{3}$ \\
\hline$Q_{i}$ & $A_{2}>A_{1}>A_{3}$ \\
\hline
\end{tabular}


The obtained results are as follows:

- $\quad A^{* *}=A_{2}$ and $A^{*}=A_{1}$ (Q ranking);

- $A d v=0.59>0.09$ and $A_{2}$ is the best ranked according to $\mathrm{S}$ ranking.

Therefore, it can be concluded that Cond.1 and Cond.2 are satisfied and alternative $A_{2}$ is the best-ranked one according to $\mathrm{Q}$ and $\mathrm{S}$ ranking.

A prototype is developed to conduct decision makers during the LMS Vikor selection process. Below are some screenshots of its different modules. As shown in Figure 3, the DM has to select the number of criteria and alternatives, then to enter their corresponding linguistic fuzzy scales.

The collected information related to LMS decision makers' preferences shown in Table 6 are entered (i.e.; Figure 4). Then the tool performs all the Fuzzy Vikor steps previously detailed and delivers two .txt files. The first file contains the pairs criteria/weight accordingly to DM's evaluations (Figure 5) for the selected LMS. The second file shown in Figure 6 contains the ranking of the different alternatives according to $\mathrm{S}, \mathrm{R}$ and $\mathrm{Q}$ indices.

\section{RESULTS AND DISCUSSION}

The obtained results show that alternative $A_{2}$ is the best compromise solution. So the open source LMS Moodle is recommended for higher Saudi institutions according to the criteria selected by the

Figure 3. Screenshots of (a) criteria and their linguistic fuzzy scales (b) alternatives and their linguistic fuzzy scales

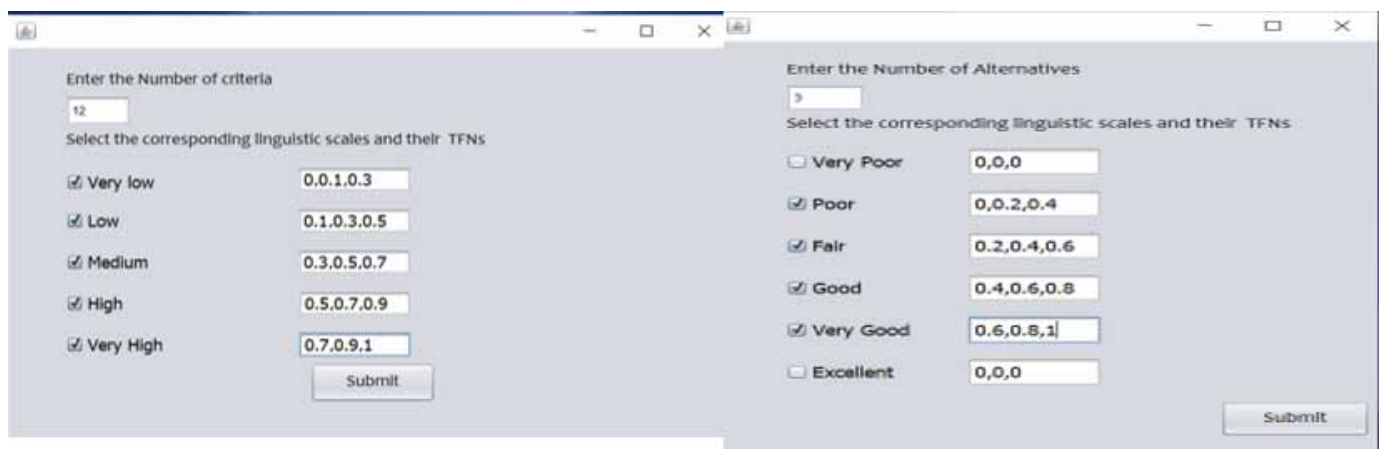

Figure 4. Screenshots of (a) criteria names entering (b) alternatives names entering
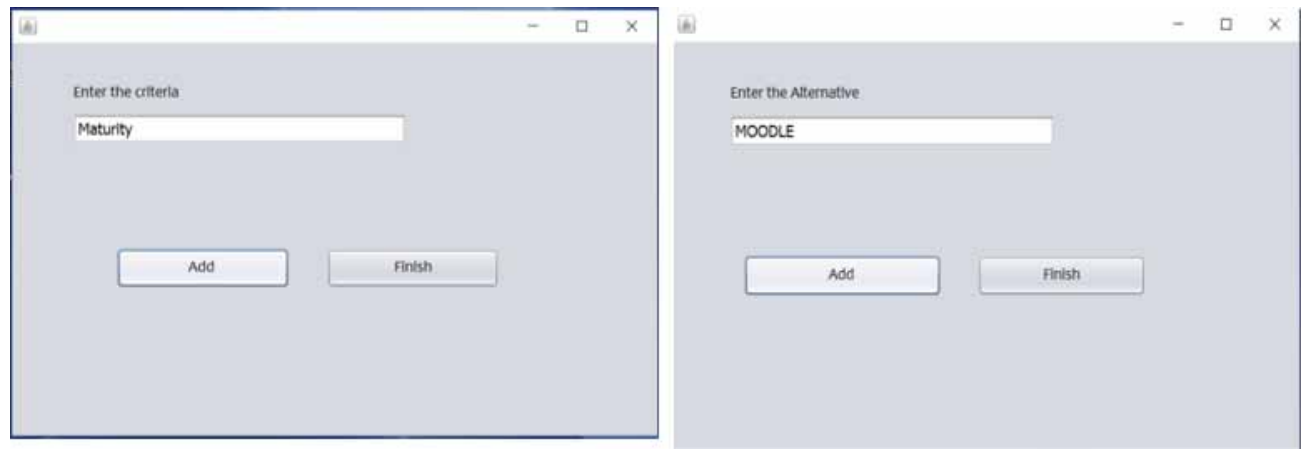
Figure 5. Screenshot of DM' preferences entering

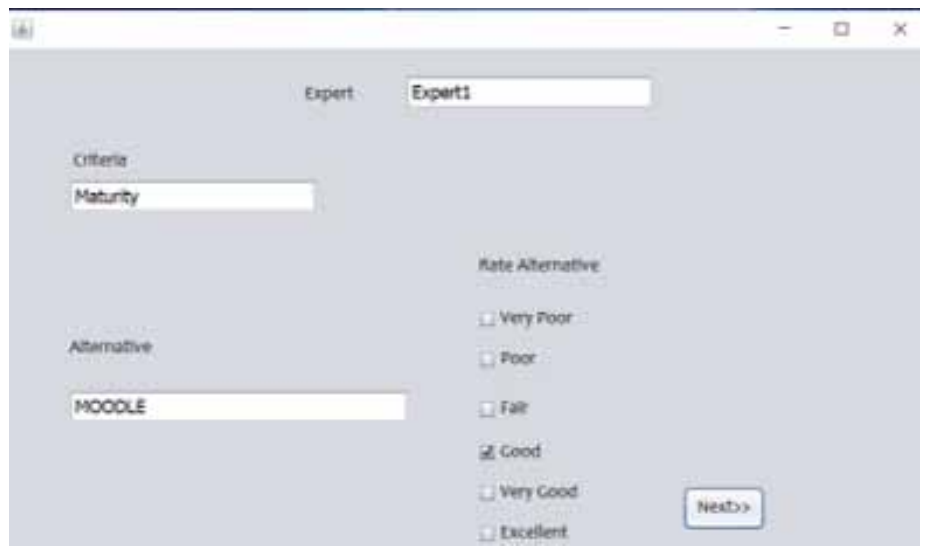

Figure 6. The result files

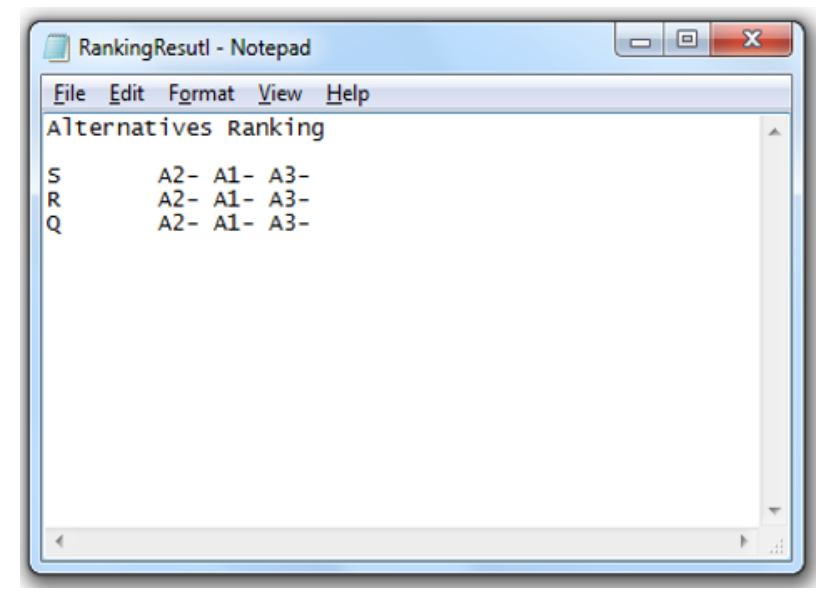

decision makers. In another hand, this case study shows that time behavior and understandability are the most important criteria in higher institutions.

These results are aligned with the ones obtained in (Xhaferi, Bahiti, \& Imeri, 2015)and (Turker \& Turker, 2019). In fact, Ülker and Y1lmaz (Ülker \& Yilmaz, 2016) found that open source LMSs (Moodle) are appropriate for companies operating in the field of technology with motivation and competencies open to development. In (Turker \& Turker, 2019), Alturn Turker et al. affirm that based on content management and development criteria, Moodle is also recommended as the appropriate LMS solution for Turkish universities.

We think that it is obvious that open source LMSs are more suitable for higher institutions and this for many reasons. First, as the number of enrolled students vary each year or every semester a year, universities do not have to pay for useless or extra licenses unlike the case of proprietary or cloud based LMSs (a free LMS could serve for 50 users or 5,000 users with the same quality). Second, Moodle presents the advantages to be user-friendly; so students do not spend much time to be familiar; and to respond quickly to students or instructors requests.

Based on the findings of this study, we recommend open source LMSs (e.g. Moodle) in higher institutions, especially with limited budget, with many branches in different cities and for those 
offering postgraduate programs. Moreover, open source LMSs are interesting to adopt in special crises situations (pandemics, natural disasters, etc.) where universities have to switch from face to face classes to virtual classes.

\section{CONCLUSION AND FUTURE WORK}

In this paper, we evoke the LMS evaluation and selection problem in higher institutions and the missing of decision support tools to guide LMS' stakeholders in this complex task. In fact, due to the big amount of LMS solutions and to particular features of every LMS, decision makers feel confused and unwilled to make some judgments. In this study, we propose a set of quality based criteria, which are important to consider for evaluating LMSs. The importance of such criteria is stressed especially in higher institutions where courses, grading, training and assignments are mostly moving to e-learning environment. This fact, conducts us to propose a help for decision makers in higher institutions for the selection of the LMS that suits their objectives.

We apply a fuzzy Vikor technique to define the criteria importance and to select the best and appropriate alternative. Three LMS solutions are evaluated for Saudi Arabia universities. The results show that Moodle emerges the best solution between Blackboard and D2L. This seems to be logic as higher institutions are more e-Learning oriented, especially with dispersed branches and selflearning/training students. Besides, Saudi universities are moving to autonomous financing and budget constraints will influence the LMS investment decision.

Moreover, we think that these results are beneficial for developers of LMS solutions to improve and increase LMS' competitiveness in higher education.

For future work, we propose to explore other quality criteria for LMS evaluation. In the other hand, we suggest the application of other MCDM techniques (Fuzzy AHP, Fuzzy TOPSIS) or hybrid approaches where interdependences and relationships between criteria are to consider instead of soliciting the criteria' weights directly from decision makers. Furthermore, we intend to enhance the LMS evaluation prototype via the incorporation of a larger set of criteria and a combination of MCDM techniques.

\section{ACKNOWLEDGMENT}

This research was funded by the Deanship of Scientific Research at Princess Nourah bint Abdulrahman University through the Fast-track Research Funding Program. 


\section{REFERENCES}

Abdel-Maksoud, N. F. (2018, Jan). The Relationship between Students' Satisfaction in the LMS 'Acadox' and Their Perceptions of Its Usefulness, and Ease of Use. Journal of Education and Learning, 7(2).

Albarrak, A. I., A. H. (2010). Evaluating learning management systems for university medical education. International Conference in Education and Management Technology (ICEMT). doi:10.1109/ICEMT.2010.5657569

Alice, P. S., A. A. (2012). A semantic based approach to organize eLearning through efficient information retrieval for interviewpreparation. In International Conference on Recent Trends in Information Technology (ICRTIT) (pp. 151-156). IEEE.

Aljuhney, Y., \& Muray, L. (2016). A Comparison of the Utilization of E-learning Management Systems in the Republic of Ireland and Kingdom of Saudi Arabia: A Case Study (2015). International Journal on Recent and Innovation Trends in Computing and Communication, 1-12.

Althobaiti, M., \& Mayhew, P. (2015). Assessing the Usability of Learning Management System: User Experience Study. International Conference on E-Learning, E-Education, and Online Training.

Bazzazi, A., Osanloo, M., \& Krimi, B. (2011). Deriving preference order of open pit minesequipment through MADM methods: Application of modified VIKOR method. Expert Systems with Applications, 38(3), $2550-2556$. doi:10.1016/j.eswa.2010.08.043

Bellman, R. E., \& Zadeh, L. A. (1970). Decision-making in a fuzzy environment management. Science, 17, $141-164$.

Best Coporate LMS Software for 2019. (2019, June 5). Retrieved from G2 Crowd: https://www.g2.com/ categories/corporate-lms

Büyüközkan, G., Arsenyan, J., \& Ertek, G. (2010). tEvaluation of e-learning web sites using fuzzy axiomatic design based approach. International Journal Computer Intelligent System, 1(3), 28-42. doi:10.1080/187568 91.2010 .9727675

Cavus, N., \& Zabadi, T. (2014). A Comparison of Open Source Learning Management Systems. Procedia: Social and Behavioral Sciences, 143, 521-526. doi:10.1016/j.sbspro.2014.07.430

Chourishi, D., Buttan, C. K., Chaurasia, A., \& Soni, A. (2011, November). Effective E Learning through Moodle. International Journal of Advance Technology \& Engineering Research, 1(1).

Chua, B. B., \& Dyson, L. E. (2004). Applying the ISO 9126 model to the evaluation of an e-learning system. ASCLITE Conference Proceedings.

Dube, S., \& Scott, E. (2014). An empirical study on the use of the Sakai Learning Management System (LMS): Case of NUST, Zimbabwe. Proceedings of the e-Skills for Knowledge Production and Innovation Conference, 101-107.

Fardinpour, A. P., Pedram, M. M., \& Burkle, M. (2014). Intelligent Learning Management Systems: Definition, Features and Measurement of Intelligence. International Journal of Distance Education Technologies, 12(4), 19-31. doi:10.4018/ijdet.2014100102

Ghazal, S., Aldowah, H., Umar, I., \& Bervell, B. (2018). Acceptance and Satisfaction of Learning Management System Enabled Blended Learning Based on a Modified DeLone-McLean Information System Success Model. International Journal of Information Technology Project Management, 9(3), 52-71. doi:10.4018/ IJITPM.2018070104

Ghosh, A., Nafalski, A., Nedic, Z., \& Wibawa, A. (2019, March). Learning management systems with emphasis on the Moodle at UniSA. Bulletin of Social Informatics Theory and Application, 3(1), 13-21. doi:10.31763/ businta.v3i1.160

Hall, J. L. (2019, July 12). Assessing Learning Management Systems, Retrieved from Learning Delivery: https:// www.chieflearningofficer.com

Hill, P. (2017). State of Higher Ed LMS Market for US and Canada. LMS \& Learning Platforms. 
Iş1k, A. H., Ince, M., \& Yagit, T. (2015). A Fuzzy AHP Approach to Select Learning Management System. International Journal of Computer Theory and Engineering, 499.

Jahan, A., Mustapha, F., Ismail, M. Y., Sapuan, S. M., \& Bahraminasab, M. (2011). A comprehensive VIKOR method for material selection. Materials \& Design, 32(3), 1215-1221. doi:10.1016/j.matdes.2010.10.015

Kang, T. H., Kuo, S. Y., Jia-Hong, S., \& Sheng-Min, W. (2011). The study for selecting theconsignment performance of e-learning of technology college. In International Conference on Multimedia Technology (ICMT) (pp. 3285-3288). IEEE.

Kim, Y., \& Chung, E. S. (2013). Fuzzy VIKOR approach for assessing the vulnerability of the water supply to climate change and variability in South Korea. Appl. Math.Mode, 9419-9430.

Lameras, P., Levy, P., Paraskakis, I., \& Webber, S. (2012). Blended university teaching using virtual learning environments: Conceptions and approaches. Instructional Science, 40(1), 141-157. doi:10.1007/s11251-0119170-9

Li, L., \& Lee, L. (2016). Computer Literacy and Online Learning Attitude toward GSOE Students in Distance Education Programs. Higher Education Studies, 6(3), 147-156. doi:10.5539/hes.v6n3p147

LMS. (2019, December). Retrieved from Communication and Information Technology: http://www.citc.gov.sa

Mastalerz, M. W. (2010). Electre method for choosing an e-learning platform. ProIn ceedings of VIth International Conference on Perspective Technologiesand Methods in MEMS Design (MEMSTECH) (pp. 168-171). IEEE.

Meirani, H., \& Adrian, S. (2018). Determinants of student satisfaction in online tutorial. Turkish Online Journal of Distance Education.

Moonsamy, D., \& Govender, I. (2018). Use of Blackboard Learning Management System: An Empirical Study of Staff Behavior at a South African University. Eurasia Journal of Mathematics, Science and Technology Education, 3069-3082.

Muhammad, M. N., \& Cavus, N. (2017). Fuzzy DEMATEL method for identifying LMS evaluation criteria. Procedia Computer Science, 120, 742-749. doi:10.1016/j.procs.2017.11.304

Opricovic, S. (1998). Multi-Criteria Optimization of Civil Engineering Systems. Facultyof Civil Engineering.

Padayachee, I., Kotze, P., Van, A., \& Van der Merwe, A. (2010). ISO 9126 external systems quality characteristics, sub-characteristics and domain specific criteria for evaluating e-Learning systems. SACLA 2010 Conference.

Persico, D., Manca, S., \& Pozzi, F. (2014). Adapting the Technology Acceptance Model to evaluate the innovative potential of e-learning systems. Computer Human Behaviour. doi:10.1016/j.chb.2013.07.045

Safari, H., Faraji, Z., \& Majidian, S. (2014). Identifying and evaluating enterprise architec-ture risks using FMEA and fuzzy VIKOR. Journal of Intelligent Manufacturing.

Sanchez-Garcia, L. F., Amat, S. S., Molina, N., \& Saiz-Colomina, S. (2018). Schoology as an alternative to traditional teaching tools for university students. 10th International Conference on Education and New Learning Technologies. doi:10.21125/edulearn.2018.1754

Shemshadi, A., Shirazi, H., Toreihi, M., \& Tarokh, M. J. (2011). A fuzzy VIKOR method for supplier selection based on entropy measure for objective weighting. Expert Systems with Applications, 38(10), 12160-12167. doi:10.1016/j.eswa.2011.03.027

Sun, P. C., Tsai, R. J., Finger, G., Chen, Y. Y., \& Yeh, D. (2008). What drives a successful e-Learning? An empirical investigation of the critical factors influencing learner satisfaction. Computers \& Education, 50(4), 1183-1202. doi:10.1016/j.compedu.2006.11.007

Turker, T. B., \& Turker, Y. A. (2019, April). the evaluation of learning mangement systems by using fuzzy AHP, Fuzzy Topsis and an integrated method: A case study. Turkish Online Journal of Distance Education-TOJDE, 20,2 .

Ülker, D., \& Yilmaz, Y. (2016). Learning Management Systems and Comparison of Open Source Learning Management Systems and Proprietary Learning Management Systems. Journal of Systems Integration, 18-24. 
Xhaferi, G., Bahiti, R., \& Imeri, F. (2015). Integrating LMS in Teaching and Learning Process in State University of Tetovo: Issues and Challenges. International Scientific Conference Computer Science.

Yanbing, J., \& Aihua, W. (2013). Extension of VIKOR method for multi-criteria group decision making problem with linguistic information. Applied Mathematical Modelling.

Yücenur, G. N., \& Demirel, N. C. (2012). Group decision making process for insurance company selection problem with extended VIKOR method under fuzzy environment. Expert Systems with Applications, 39(3), 3702-3707. doi:10.1016/j.eswa.2011.09.065

Zarea, M., Pahlb, C., Rahnamad, H., Nilashiaf, M., Mardanie, A., Ibrahima, O., \& Ahmadia, H. (2016). Multicriteria decision making approach in E-learning: A systematic review and classification. Applied Software Computing, 108-128.

Sarra Ayouni has a PhD in computer science (2012/2013), from the Faculty of Sciences of Tunis (FST) and from the University of Montpellier 2 (France). She is specialized in Data mining filed. She is actually assistant Professor in Information Systems department of the College of Computer and Information Sciences in Princess Nourah Bint Abdulrahman University (PNU) and she is currently the Distance Education Coordinator of the college.

Leila Jamel Menzli (PhD) is an assistant professor in the College of Computer and Information Sciences at Princess Nourah Bint Abdulrahman University, KSA. She is a researcher in RIADI Laboratory. She has a Ph.D. in computer sciences- Business Process Reengineering and Modelling, and an engineering degree in Computer Science. Her research interests are include Business Process Modelling, Business Process Management/Reengineering and Quality, Context-Awareness in Business Models, Process Mining, e-learning, a software engineering. She worked as a HOD of the Information Systems Security at the Premier Ministry in Tunisia. She is the reviewer of many international journals. She was a member steering and scientific committee of the IEEE International Conference on Cloud Computing (ICCC'15) 2015.

Fahima Hajjej has a PhD in computer science (2016/2017), from the Faculty of Sciences of Sfax. She is actually an assistant professor in the Department of Information Systems, College of Computer and Information Sciences at PNU, Saudi Arabia. She is a member of the Research Laboratory in Technologies of Information and Communication and Electrical Engineering (LaTICE). Her research interests include the modelling concepts of e-learning, e-assessment, integration of formal and semi-formal methods, Data science and Big data.

Mohamed Maddeh has a PhD in computer science (2012/2013), from the National school of Computer Sciences of Tunis (ENSI) and member of Optimization Strategies and Intelligent Computing laboratory (SOIE) located at Higher Institute of Management of Tunis. He is specialized in software engineering filed. He is actually assistant Professor in King Saud University (KSA).

Shaha Al-Otaibi (PhD) is an assistant professor in the Department of Information Systems, College of Computer and Information Sciences at PNU, Saudi Arabia. She received her MS in Computer Science, and PhD in Artificial Intelligence from KSU. She also has SFHEA, the Senior Fellow Recognition from UK Higher Education Academy. Currently, she is a reviewer in some Journals and editorial board member in Journal of Advanced Database Management \& Systems (elSSN-2393-8730), Journal of Web Engineering \& Technology (elSSN-2455-1880), and Journal of Artificial Intelligence Research \& Advances (eISSN-2395-6720). Her main research interests include: Data Science, Artificial Intelligence, Cybersecurity and Information Security, Bio-inspired computing. 